\title{
Financial Market Integration: New Challenges for Regulation in Europe and Beyond
}

In this issue of EBOR we present a series of articles on a common theme: the regulation of increasingly integrated financial markets.

The European Union has made major efforts over the past fifteen years to enhance financial market integration and at the same time to develop a legal and regulatory infrastructure for them. The first two articles by Guido A. Ferrarini and Niamh Moloney are devoted to the experience of the EU and address issues of regulating national and pan-national markets, as well as market intermediaries, such as investment services providers. In addition, the case note on the recent Golden Shares decisions by the European Court of Justice by Paulo Câmara highlights the important role the ECJ is playing in furthering the process of European integration.

Europe, of course, is not alone in facing the need to respond to the forces of international financial market integration. A view from across the Atlantic by Merritt B. Fox addresses global securities market regulation from a US perspective. Until recently, the US has been a focal point of global financial market integration attracting firms from Europe, Latin America and elsewhere, which "migrated" to US markets to take advantage of lower capital costs and/or to signal their commitment to strong securities market regulation. This phenomenon has raised important questions about the possible and desirable reach of US regulation and about alternatives to national market regulatory models.

Historically, and from the perspective of some countries (in particular the UK), the most important regulators of securities markets have been stock exchanges. They still play an important role today, mostly in a complementary role to state regulators. But how well are stock exchanges placed to ensure effective rule-making and rule-enforcement in an increasingly integrated world? Do they cooperate or compete and what implications do these different strategies have for regulating financial markets? Nis Jul Clausen and Karsten Engsig Sørensen address these questions. Empirical data analysis on the present status and future of stock exchange, especially in emerging markets, suggests that the landscape of stock exchanges is currently in flux. As evidenced in the contribution by Stijn Claessens, Daniela Klingebiel and Sergio L. Schmukler, many of the markets that have, only recently, been established in the former socialist countries are unlikely to survive in their current form as a result of economic forces that drive consolidation and further integration. This trend alone does not appear to make financial market regulation at the national or subnational level superfluous. It does, however, change the role of national 
regulators and the function of local markets. Taking these trends into account seems to be important when designing the architecture for pan-European or international financial markets. Some of the design features seem to assume the existence of comparable national markets as well as national market regulators. Yet, we might soon be witnessing the withering away of some of these building blocks or, at least, a change in their outlook.

Financial Markets consist not only of the instruments traded, but also of issuers, investors, and intermediaries, with the latter playing an increasingly important role. With the growing role of institutional investors that operate internationally the landscape of owners of firms has changed in most countries that have opened their doors to international capital flows. Changes in the ownership types may well result in changes for corporate governance. Institutional investors are probably better informed and more sophisticated than individual investors. They are more likely to take action either informally or formally. Mette Neville analyzes institutional investors as the new owners of firms in Europe and suggests how they could change the way in which we conduct corporate governance. Finally, Klaus Heine and Erich Oltmanns take a fresh look at what drives investor decision-making. They employ psychological theories that explore the motives for control. Using this framework, they develop indicators to test psychological control theories as an alternative to the nowadays widely used database on minority shareholder protection in civil and common law systems. Their results suggest that we are only beginning to understand the inter-relation between law, finance, and investor behavior.

Financial market integration is a moving target. This special issue of EBOR was designed to take a broad look at some of the bigger themes, including those that might not be readily accessible to a legal audience. We do not claim to have exhausted the topics. The goal was to stimulate debate and further research in this area and we hope to see responses and further elaborations on the theme in future issues of EBOR.

Katharina Pistor

Editor of this special issue 